\title{
Attachment Relationships and Learned Resourcefulness Levels of Institutionalized Adolescents
}

\author{
Hacer Subasi*, Nadire Gulcin Yildiz \\ Istanbul Medipol University, Department of Psychological Counseling and Guidance, Turkey
}

\begin{abstract}
Attachment as a very important regulator of both emotions and the self and learned resourcefulness (LR) as a both cognitive and emotional-regulation strategy seems very interrelated. It is thought that, more secure attachment relationships lay the foundations of high capability of learned resourcefulness. This cross-sectional survey study aims to investigate the relationship between LR and attachment relations among adolescents according to whether they reside in care or with their families. To this end, data was collected from 61 adolescents with convenience sampling method, including 31 living with their families from Istanbul's Huseyin Avni Sozen High School and 30 residing at foster care institutions. The total number of participants in this study came to 61, with an average age of 17. The Adult Attachment Scale (AAS), Inventory of Parent and Peer Attachment (IPPA)-Short Form and Rosenbaum's Learned Resourcefulness Scale (RLRS) were used for data collection. It was found that institutionalized adolescents (IA) had a higher sense of insecurity in their attachment relationships than adolescents who stayed with their families (ASF). In addition, while there was a significant relationship between learned resourcefulness and attachment styles, those living with their families had higher scores on a number of RLRS sub-dimensions than those who stayed in institutions $(\mathrm{p}<.05)$. Discussion: The study findings already present in current literature on the issue were discussed and interpretations drawn, and it was deemed that institutional factors were important in terms of attachment relations and learned resourcefulness in adolescents living in care homes.
\end{abstract}

Keywords: Attachment, Attachment relationships, Institutional care, Learned resourcefulness, Resiliency.

\section{INTRODUCTION}

Attachment refers to human's innate tendency to form social bond from cradle to grave' (Bowlby, 1979, p 129) to a specific significant other who is responsible for giving care, providing support and protection by encouraging and preserving proximity of the individual to its caregiver (Bredeistine et al., 2011).

Despite the majority of literature on social relations, attachment theory appears the most substantial one. This is a very important contribution to the field, since attachment relationships play a very major role in human life by influencing and shaping emotion regulation strategies, selfregulation strategies, cognition, coping strategies, resiliency, sociability, neurobiological development, predisposition to psychopathologies and so on (Bowlby, 1979; 1988; Cassidy, 1994; Sroufe, 2005; Weinfield et al., 2008). There is ample evidence to suggest that attachment is an important variable in human development (Thompson \& Newton, 2009; Sroufe, Coffine \& Carlson, 2010). Attachment relationships influence behavioral patterns of an individual. When an individual develops secure attachments, they could rise above against all the odds, in the face of adversities (Thompson, 2009; Thompson \& Newton, 2009).

Interpersonal consistency has a key role in regulation of both self and emotion in close relationships. When it comes to attachment relationships, primary caregiver as the first opening door to the social world serves as a foundation for the child to regulate him/her self and his/her emotions depending on accumulation of the experiences with the caregiver in terms of its availability during stress, sensitivity to the needs, consistency and responsiveness.

Depending on these factors, four different types of attachment styles have been classified. Initial classification had been made by Ainsworth and her colleagues (1978) as; a) secure, b) anxious/ambivalent and c) avoidant attachments. However, in 1990 Solomon and Main had discovered a fourth category of attachment which is known as disorganized attachment. This new addition of new category leads them to revise the initial classification with a major two different types as organized and disorganized in which organized attachment itself consists of two major different attachment styles as secure and insecure. Insecurity of attachment refers to both anxious/ambivalent and avoidant attachment styles.

\section{Corresponding Author e-mail: hacer.subasi@yahoo.co.uk} https://orcid.org/0000-0002-1801-6209

How to cite this article: Subasi H, Yildiz NG (2022). Attachment Relationships and Learned Resourcefulness Levels of Institutionalized Adolescents. Pegem Journal of Education and Instruction, Vol. 12, No. 1, 2022, 100-114

Source of support: Nil

Conflict of interest: None.

DOI: $10.47750 /$ pegegog.12.01.10

Received: 29.08 .2021

Accepted: 02.11.2021

Publication: 01.01.2022 
With this perspective, attachment relationships have begun to be evaluated as 'organizational constructs' instead of 'trait constructs' (Sroufe \& Waters, 1977) that enable individuals to organize themselves in emotional, cognitive and social manner in a consistent and predictable way during stressful life events. With this respect disorganized attachment style refers to inability of one's own self and emotions in an effective way in stressful life events. In other words, it means a kind of regulatory incapacity manifested as conflict about if and to what extent to 'approach to' and 'distance from' the 'out of sync' caregiver (Levy \& Orelans, 2000) who is both source of security and fear (Hesse \& Main, 2000). However, organized attachment styles regardless of being secure or insecure refers to being able to organize self and the emotions consistently in case of stress. While an avoidant attachment type manifests itself with an 'organized' of self-distancing and dismissive behavioral pattern an anxious/ambivalent attachment type manifests itself with an 'organized' excessive dependence to others and demanding behavioral pattern. Lastly, secure attachment style refers to being a flexible tidal behavioral pattern between 'proximity '5trseeking and 'distancing' behaviors with full confidence to self and others. Furthermore, it must be mentioned that the cognitive schemas behind those behavioral manifestations of different attachment styles thought to be constructed through the internalization of images of 'self' and 'others' as a result of the accumulation of the attachment experiences with the caregiver. Those cognitive schemas are known as 'Internal Working Modes (IWMs)' in attachment literature. IWMs are relationship specific constructs and can be updated through new experiences and cognitive abilities. Caregiver's availability and responsiveness to the needs of a child enable the child to organize its own emotional experience, regulate "felt security" and construct a positive image of self and significant others. Therefore, while securely attached individuals tend to have positive images of both 'themselves' and 'others' which in turn manifested as a sense of being loved from others and belief in being worth to be loved; individuals who have disorganized attachment tend to have negative images of both 'themselves' and 'others which in turn manifests itself as the opposite of secure type. Accordingly, while attachment avoidance associated with positive 'self' image and negative 'others' image, attachment anxiety associated with 'negative 'self' image and positive 'others' image (Bartholomew and Horowitz, 1991).

Emotion-regulation and self-regulation are natural developmental processes derived from both cognitive and emotional internalization of attachment experiences. In times of stressful life events, individuals turn to others to solve problem or reject the support from others. So, IWMs as organizational constructs derived from attachment relationships play a crucial role in dealing with stress determining one's ability to organize own self, cooperate with others, problem solving strategies, accepting emotional or instrumental support (Cutrona, 1990) and so on. For example, while individuals with attachment avoidance were found to be cope with the problems dismissively by excessive self-reliance and unable to seek support due to their 'negative others image', individuals with attachment anxiety were found to be cope with problems by compulsive dependence to others to seek support and use more emotionoriented strategies (Mickulincer \& Florian, 1997). Accordingly, individuals can develop ability to cope with stressful life events depending on their ability to regulate themselves and emotions in addition to their perception about external life events to be controllable or uncontrollable known as conflict perception (Ben Ari \& Hirshberg, 2009; Pasyar, Rezaei and Mousavi, 2018). Thus, attachment security ensures individual's belief in that others will be ready for emotional support and they are worth to receive this support in stressful situations through their IWMs about self and others which in turn results in high resilience.

Studies in last three decades also confirm that individual differences in attachment styles may have important implications for resiliency, or with original saying 'learned resourcefulness (LR)' as it constitutes a foundational base for coping with the stressful life events effectively, seeking support from others ability to control one's own self (Ognibene and Collins, 1998; Ceyhan, 2006; Dilmaç, Hamarta \& Arslan, 2009) (Meichenbaum (1977) was the first to identify the concept of "learned resourcefulness" (LR) as a form of self-regulation and coping strategy. According to Meichenbaum, LR is a kind of array of attitudes that allow individuals to cope with stressful life situations as well as to exert self-control over them. In his view, $\mathrm{LR}$ is manifested through a) ability to monitor dissonant thoughts, incompatible images, emotions, and behaviors; b) problem-solving skills; c) emotion-regulation and self-control strategies.

Rosenbaum (1983, p.66), however, defined LR as an "acquired repertoire of behaviors and skills by which a person self-regulates internal events". Similarly, according to him LR is a kind of cognitive and behavioral strategy that allows individuals to regulate internal stimuli that constitute an obstacle to that individual's desired behavior (Rosenbaum and Jaffe, 1983, p. 216). In this sense, LR not only refers to self-efficacy to cope with stress, but also self-regulation ability under stress. In accordance with this idea, a self-regulation strategy can be evaluated as LR if only it minimizes the effect of inconsistent internal states that prevent individuals from achieving a goal (Rosenbaum \& Jaffe, 1983).

In this regard, LR consists of four basic components which are a very essential qualifications of secure attachment style as well : a) the use of self-statements to manage emotional responses, b) the use of problem-solving strategies, c) delay of gratification and d) perceived self-efficacy which refers to 
one's own capacity of self-control on internal states. Therefore, individuals with high LR are more likely to use active coping strategies than individuals with low LR as they can tolerate the effects of negative life events effectively through a flexible and healthier self-regulation (Rosenbaum and Ben-Ari, 1985) as securely attached individuals did.

Attachment as a very important regulator of both emotions and the self and LR as a kind of coping strategy seems very interrelated. It is thought that, more secure attachment relationships lay the foundations of high capability of learned resourcefulness. institutionalized children are more prone to suffer from disorganized or insecure attachment relationships due to toxic family ecosystems, maltreatment, abuse, neglect, or a host of other factors (Dozier \& Rutter, 2008). Unsurprisingly, impaired attachment relationships caused by pathogenic care of parents or caregiver interferes with development of secure attachment and leads severe maladaptation (Liang, Wiliams and Siegel, 2006; Dozier, Stovall-McClough \& Albus, 2008). While pathogenic ecosystem and maltreatment constitutes the first trauma, forcibly being separated from their families and social environment constitutes a second trauma for them. Such an experience of forced separation may induce insecure or disorganized attachment as a reactionary self-control strategy. Thus, children who suffer from attachment disorganization or insecurity in dysfunctional ecosystems may continue to feel its effect after placement into institutions which is the most widespread method used to protect them. However, in the psychological sense, these places are rather inadequate in terms of restoring a child's essential attachment relationship as a means of rehabilitation (Yolcuoglu, 2009; Bayogglu \& Purutcuoglu, 2011).

While the current literature shows similarities between those with a high degree of LR and the characteristics of those with secure attachment, those with a lower level of LR show similarities with the characteristics of those with more insecure attachment (Huang, Sousa, Tu \& Hwang, 2005; Ceyhan, 2006; Dilmac, Hamarta \& Arslan, 2009; Ronen \& Rosenbaum, 2010; Eroglu et al., 2014). Beliefs that purport a lack of control in the face of stressful situations and a feeling of hopelessness are a strong indicator of low LR (Gintner, West \& Zarsky, 2001). With this in mind, it is most likely that institutionalized children and adolescents will display low LR. Thus, the first goal of this study is to analyze the attachment relationship of adolescents and to determine whether the attachment organization differs in relation to being stayed in institutions or with their families. The second goal of the study is to investigate the LR of individuals. The third goal of the study is to examine the potential relationship between attachment styles and LR. As part of these aims of the study, those research questions will be addressed: 1) Do adolescents who stayed in institutions show lower level of LR? 2) Do adolescents who stayed in institutions have more attach- ment insecurity? 2) Is there a positive correlation between attachment security and high LR? 4) Does attachment relationship play a mediatory role between LR and staying in institutions or staying with families?

In Turkey, most of the studies about institutionalized youth generally focus on after the period of institutionalization by examining their resiliency (Turgut, 2018), predisposition to various psychopathologies (Turgut \& Ozkan, 2019; Yildiz \& Bilge, 2020), job and life satisfaction (Cifci et al., 2016), some socio-demographic variables (e.g., income, employment level, education) (Saglam, 2014) and so on. An important reason of this might be its difficulty to reach those individuals due to red tape and unwillingness of principals of institutions to participate in such investigations. Furthermore, comparative studies between IA and ASF in terms of any variable is less likely to be done than non-comparative studies (Yildiz \& Bilge, 2020).. Given that before this study, there existed only one research examining the level of LR of adolescents with an attachment perspective depending on the criteria of living in institutional care or living with parents (Boyraz \& Aydin, 2003). This research (2003) comparing adolescents who stayed with their families to those residing in Fatma Ucer, Gazi Girls Orphanage, $50^{\text {th }}$ Anniversary Orphanage and Ataturk Child Care Center found that non-institutionalized adolescents showed significantly higher levels of LR compared to institutionalized adolescents (IA). Recently, there is one more study revealing that the level of care and love received from caregiver and caregiver's ability of problem solving predicted the LR level of institutionalized children (Ozturk, 2018). However, as this research did not take attachment relationships into consideration as an independent variable it is rather though to draw direct comparisons. As of the time of writing, there has been no relevant study found on the subject, except for Boyraz and Aydin's research (2003) investigating only LR of adolescents in terms of living with family and in institutions.

The literature appears to lack any research at all on the links between LR and attachment relations not only among children living in institutional care but also among normal population. To our knowledge, our study is the first in the literature by focusing on the relationship between LR and attachment patterns of Turkish adolescents who live in institutions and with their families. That is, the present study will constitute the first Turkish investigation into the matter by analyzing the of adolescents in terms of living with family or in institutions with an attachment perspective. Therefore, this study is in a very special position as it analyzes the association between LR and attachment on a comparative context. As well as testifying to the importance of the study, the findings can pave the way for further discussions based on the literature review and relevant research that already exist. Fortunately, these potential research and discussions about the topic may affect the decisions and policies taken by policy makers, nongovernmental organizations and other related institutions in 
the subject and make it possible for the youth at risk to involve in o the society as healthy individuals.

\section{Method}

\section{Participants}

The study takes as a sample 31 adolescents staying with their families (ASF) with an average age of 18, who study at Istanbul's Hüseyin Avni Sözen Anatolian High School, along with 30 institutionalized adolescents with the average age of 16 studying at a number of high schools in Istanbul. Thus, the total number of adolescents in the sample group comes to 61 , with 50 being female and 10 being male. Each participant in the study was given the necessary information about its nature and volunteered their participation both verbally and in writing. Socio-demographic data relating to the participants has been detailed in the table below.

\section{Research Procedures}

In order to investigate the link between LR and attachment relations, this study harnesses the Inventory of Parent and Peer Attachment (IPPA) short form, the Adult Attachment Scale and the Learned Resourcefulness Scale. The research was carried out with a framework in which the socio-demographic variables (for example age, education level, etc.) and staying with families and staying in institutions have been taken as independent variables, attachment and LR have been taken as dependent variables.

\section{Data Collection Instruments}

Personal Information Form: This form was handed out in order to acquire the participants' personal information in terms of age, sex, socioeconomic state, education, homelife etc. Only the experimental group was asked to answer an extra four questions including a) "How old were you when you entered the institution?" b) "How long have you stayed?" c) "Who is the worker you have gone to most frequently with personal issues?" and d) "How many members of staff are there to support you?"

Adult Attachment Scale (Hazan \& Shaver, 1987). The scale was compiled as a categorical self-report measurement tool to measure three types of attachment - specifically among romantic adult partners. Participants were asked to choose from among three paragraphs that best suited their experience of attachment. Although categorical measures of attachment have certain psychometric limitations (Fraley \& Waller, 1998), we deemed the AAS as useful for our private sample groups given the test group of our study consisted of institutionalized adolescents, who suffer from various psychopathologies that hinder their cognitive abilities. This is on the basis of its being an easily read and digested, multiple choice scale. Furthermore, the limits of the IPPA-short form to test romantic attachment was another reason we included this measure, due to a major shift in attachment relationships from parents to peers and romantic partners occurs during adolescence.

The Inventory of Parent and Peer Attachment-short form (IPPA, Raja, McGee \& Stanton, 1992):

The psychometric analysis of the parental forms of the IPPA-short form for the Turkish population were carried out by Gunaydın et al. (2005). As a result, a high internal consistency was obtained with two valid Cronbach's alpha value for the parental form came to .88 for the father form and .90 for the mother's $(p<.01)$ with the exclusion of 6 th item due to its poor factor loading. As part of this study, the total Cronbach Alpha's value of the IPPA-short form came to .81 for the mother form of the control group and .82 for the experimental group and .89 for the father form of the control group and .86 for the experimental group $(p<0,01)$.

Originally included 28 items, which reduced to just 12 . This meant that together with the 12 -item each parent forms, the total number of items came to 24. Items 1-12 of this form pertained to the mother, while 13-24 pertained to the father. Essentially, each parental form in the IPPA was comprised of four points containing three sub dimensions - namely, trust, communication, and alienation. Of these, $6,7,12$ pertained to communication; 4, 5, 9, 10 to alienation; and 1,2,3,11 to trust. The total attachment score was arrived at by adding up these totals. The items were measured along a seven-point Likerttype scale. The values were calculated in descending order from positive to negative, i.e., 7, 6, 5, 4, 3, 2, 1. Accordingly, the highest possible score came to $7 \mathrm{X} 24=168$ and the lowest possible score came to $1 \mathrm{X} 24=24$. When calculating the total attachment score of the participants, 2,6,4,5,9, 10th items were reverse coded as the same procedure has been done in the original study.

The Rosenbaum Learned Resourcefulness Scale (RLRS): This scale was judged as valid and reliable for use among Turkish respondents by îhsan Dag (1991), whose study confirmed a test-retest reliability coefficient of $.80 \quad(p<.001$; sd.=98). Furthermore, the Cronbach's Alpha internal coefficient came to a grand total of .85 in the pre-trials of the study and .78 in among a larger sample (Dag, 1991, p.271). For this study, the RLRS Cronbach's Alpha values of the control group came to .81 and .65 for the experimental group $(\mathrm{p}<0,01)$. The RLRS is composed of a total of 36 questions, presented in the form of a five-point Likert-type scale. The maximum number of scores available came to $36 \times 5=180$, while the minimum score came to $36 \times 1=36$. The RLRS is composed of 12 sub dimensions, including: Implementation of planned behavior=33, 32, 34, 11; Mood management: 5, 13, 15,17; Management of unwanted thoughts: 4, 6, 9, 21 and 35; Management of impulse and implementation of planned behavior: 3, 7, 12, 26, 27 and 28; Self-sufficiency and self-support: 12, 16, 24,25; Pain management: 23, 31; Delay of gratification: 18, 22, 29 and 30; Seeking help: 7, 14, 19; Favorable interpretation: 1, 2,4; 
Careful supervising: 10, 11,36; Flexible planning: 20, 21,12; Seeking supervisor: 8, 9, 11,16.

\section{Data Gathering and Statistical Analysis}

The measurement scale prepared in line with the study was filled out by 31 adolescents from Hüseyin Avni Sözen Anatolian High School (control group) and 30 institutionalized adolescents staying at both Beykoz and Anadolu Social Rehabilitation Centers and studying at various schools in Istanbul (experimental group). Of the 66 forms handed out, five were deemed unusable due to random or improper answering.

\section{Results}

The average age of the control group came to $18,00 \pm 1,03$; while for the experimental group it came to $15,73 \pm 1,96$. The total average age of both groups showed no significant statistical difference $(\mathrm{p}<.05)$. The control group was made up of 10 males and 20 females, with 30 females in the experimental group. One respondent in the experimental group did not prefer to identify a gender. Of the control group, one spent their childhood in a rural area, one in a town, three in the same district and 25 in the same province as the study was conducted in, while in the control group these figures came to five, one, nine and 14 , respectively. In the control group, all respondents were of high school education, while in the experimental group, 16 finished their education at primary school and 12 were at university. While one member of the experimental group quit primary education, another respondent left the item blank. Meanwhile, from a socioeconomic perspective, a confluence of respondents was drawn from the middle class, with three from poor backgrounds, 53 from the middle and five from the upper tiers of society. Those whose fathers finished their education at primary school came to $13(21.3 \%)$, with only two of these (15.4\%) from the control group and 11 (84.6\%) from the test group. Moreover, 12 (19.6\%) of respondents' fathers completed their high school education, with five (41.7\%) of these from the control group and seven (58.3\%) from the experimental group. Those whose fathers received a university education came to 22 (36\%), two (9.1\%) from the experimental group and 20 (90.9\%) from the control group. Those who ticked "other" for the item regarding their fathers' education came to six $(9.8 \%)$, with four $(66.7 \%)$ from the control group and two (33.3\%) from the experimental group. Those whose mothers finished their education at primary school came to 18 (29.5\%), with only three of these (17.6\%) from the control group and $15(83.3 \%)$ from the experimental group. Meanwhile, 12 (19.6\%) of respondents' mothers completed high school education, with $11(91.7 \%)$ of these from the control group and one (8.3\%) from the experimental group. Those whose mothers received a university education came to 15 (88.2\%), two (11.8\%) from the experimental group. The number of those whose mothers had a university education came to a total of 17 (27.8\%).

Upon analysis, the age in which those in the experimental group were sent into care ranged from 11-16 with an average age of $14,37 \pm 1,54$. Some participants counted the duration of their stay in days - others, weeks and months. The duration of staying in institution was measured as 'at least one month' and 'maximum 84 months ( 7 years)'The data reveals an average of $21,41 \pm 22,87$ months for staying in institutions.

Factor analysis of IPPA-short forms proved it to be statistically suitable to draw conclusions with a significant Bartlett test score and KMO value of 0,784. Upon processing the data, as seen in table 2 the point averages for mother and father attachment among IA and ASF, as well as the " $\mathrm{z}$ " values that link these averages, were observed. After Mann Whitney $\mathrm{U}$ test, no significant difference was noted among the average attachment style points ( $p>0.05$ ). In conclusion, no difference was noted between IA and ASF depending on attachment security. A note on the possible causes for this is included in the discussion section.

Table 3 shows the statistically meaningful relationship between alienation from mother and trust in, communication with and alienation from fathers and total attachment scores $(<0.05)$. For the control group, a significant link was found between mother and father attachments.

The variance of AAS categories among groups were found to be statistically significant $(\mathrm{r}=-0,42 ; \mathrm{p}=0,001)$. While individuals in the experimental group were found in possession of avoidant attachment, those in the control group had secure attachment. Specifically, the $62 \%$ of the experimental group were characterized by a pattern of avoidance and $3.4 \%$ by anxious attachment. In contrast, $14.3 \%$ of the control group register for avoidant and $21.4 \%$ anxious attachment. The findings of the AAS and IPPA were rather varied and thus it was deemed necessary to investigate the links between data from both forms to examine respondents' general profile of attachment relations. This analysis has been summarized on Table 5 .

According to the data summarized on Table 7, one can see a significant statistical link between AAS results and scores gathered from communication sub-dimension of IPPA mother form and total attachment score in the control group $(p<0,05)$. Data revealed a significant relationship between the communication sub-dimensions of the IPPA father form and AAS among the experimental group $(\mathrm{p}<0,05)$.

According to the results emerged from the Mann Whitney U test and data connected with the sub dimensions of the RLRS, there appears to be a significant difference between the control group and experimental group in terms of 'Implementation of Planned Behavior' $(p=0,019)$. Statistically significant data was also garnered showing a great result in terms of 'delay of gratification' between the averages of the experimental group 
Table 1: Participants' Demographic Characteristics $(\mathrm{N}=61)$

\begin{tabular}{|c|c|c|}
\hline & Adolescents staying with their families & Institutionalized adolescents \\
\hline $\mathrm{N}$ & 31 & 30 \\
\hline$\%$ & $\% 50,81$ & $\% 49,18$ \\
\hline Age & $18,00 \pm 1,03$ & $15,73 \pm 1,96$ \\
\hline \multicolumn{3}{|l|}{ Gender } \\
\hline Male & $10(\% 33,3)$ & - \\
\hline Female & $20(\% 66,67)$ & 30 \\
\hline Other & - & 1 \\
\hline \multicolumn{3}{|l|}{ Education } \\
\hline High education & 31 & - \\
\hline Below high education & - & $16(\% 53,33)$ \\
\hline College & - & $12(\% 40)$ \\
\hline Other & & $2(\% 6,67)$ \\
\hline \multicolumn{3}{|l|}{ Social environment } \\
\hline City & $25(\% 80,65)$ & $14(\% 48,28)$ \\
\hline Without city & $6(\% 19,35)$ & $16(\% 51,72)$ \\
\hline \multicolumn{3}{|l|}{ Socio-economic status } \\
\hline Low & $1(\% 3,23)$ & $2(\% 6,67)$ \\
\hline Middle & $28(\% 90,32)$ & $25(\% 85,33)$ \\
\hline High & $2(\% 6,45)$ & $3(\% 10)$ \\
\hline \multicolumn{3}{|l|}{ Parental Education (father /mother) } \\
\hline İlliterate or drop out & $1-$ & $3(\% 100) / 9(\% 100)$ \\
\hline Primary school & $2(\% 15,4) / 3(\% 16,7)$ & $11(\% 84,6) / 15(\% 83,3)$ \\
\hline High education & $5(\% 41,7) / 11(\% 91,7)$ & $7(5 \% 58,3) / 1(\% 8,3)$ \\
\hline College & $20(\% 90,9) / 15(\% 88,2)$ & $2(\% 9,1) / 2(\% 11,8)$ \\
\hline Other & $4(\% 66,7) / 1(\% 50)$ & $2(\% 33,3) / 1(\% 50)$ \\
\hline \multicolumn{3}{|c|}{ Consulted Staff Distribution in Institution } \\
\hline Psychologist or social worker & - & $1(\% 3,3)$ \\
\hline Administration or psychologist & - & $2(\% 6,7)$ \\
\hline Social worker & - & $5(\% 16,7)$ \\
\hline Psychologist & - & $16(\% 53,3)$ \\
\hline Administration & - & $4(\% 13,3)$ \\
\hline Cook & - & $1(\% 3,3)$ \\
\hline Cook, psychologist or health prof & - & $1(\% 3,3)$ \\
\hline
\end{tabular}

and control group $(\mathrm{p}=0,033)$. Similarly, that the averages of the 'favorable interpretation' sub dimensions of the control group, at 9,55, and the test group, at 8,36 were observed, proved a remarkable statistical significance $(p=0,01)$. In terms of "mood management," "management of unwanted thoughts," "management of impulses and implementation of planned behavior," "self-sufficiency and self-support" "pain management," "seeking help," "seeking supervisor," "flexible planning" or "careful supervising" any significant relationship identified ( $\mathrm{p}>0.05)$. On the other hand, a statistically significant difference, which is not shown on the table, between males and females was detected in terms of some sub-dimensions of RLRS (implementation of planned behavior, management of unwanted thoughts, and favorable interpretation) among both male and female respondents $(\mathrm{p}<.05)$. Findings also showed an association between age and delay of gratification, seeking help and seeking supervisor among those in the test group $(\mathrm{p}<.05)$. Further, scores for delay of gratification, seeking supervisor and careful supervising increased in line with the age of the participants of experiment group, while a meaningful statistical relationship was also identified between fathers' education level and trust to mothers $(\mathrm{p}<.05)$. As the level of a father's education 
increased, scores of trust to mothers diminished. Aa significant link was also found between the 'Seeking Help' subdivision of the RLRS ( $\mathrm{p}<.05)$, as the level of education of mothers increased among experimental group participants (i.e., the stress point of 'seeking help' score increased).

Data given on Table 8 has revealed a significant relationship between attachment and education, the duration of institutionalization and the number of staff caring for the participant $(\mathrm{p}>0,05)$. In terms of the " $\mathrm{p}$ " value, a rather close comparative value of 0,05 was found between attachment styles and the age of placement of IA. A statistically significant and negative correlation was also found between attachment styles and the age upon which a youth was sent into institutional care $(r=-0,32 ; p=0,09)$.

Table 2: IPPA-shot form Psychometric Properties

\begin{tabular}{|c|c|c|c|c|c|c|c|}
\hline & & & $n$ & & Ss & $Z$ & $P$ \\
\hline \multirow{8}{*}{ 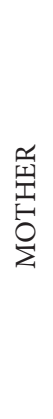 } & \multirow[t]{2}{*}{ Trust } & ASF & 31 & 21,55 & 4,21 & \multirow{2}{*}{$-1,338$} & \multirow{2}{*}{0,181} \\
\hline & & IA & 30 & 18,63 & 7,24 & & \\
\hline & \multirow[t]{2}{*}{ Communication } & ASF & 31 & 18,29 & 5,04 & \multirow{2}{*}{$-0,825$} & \multirow{2}{*}{0,409} \\
\hline & & IA & 30 & 16,40 & 5,93 & & \\
\hline & \multirow[t]{2}{*}{ Alienation } & ASF & 31 & 18,52 & 4,60 & \multirow{2}{*}{$-0,543$} & \multirow{2}{*}{0,587} \\
\hline & & IA & 30 & 17,43 & 6,59 & & \\
\hline & \multirow[t]{2}{*}{ Attachment } & ASF & 31 & 54,34 & 10,98 & \multirow{2}{*}{$-1,129$} & \multirow{2}{*}{0,259} \\
\hline & & IA & 30 & 48,68 & 15,65 & & \\
\hline \multirow{8}{*}{ 茎 } & \multirow[t]{2}{*}{ Trust } & ASF & 31 & 20,17 & 5,83 & \multirow{2}{*}{$-0,359$} & \multirow{2}{*}{0,719} \\
\hline & & IA & 30 & 18,54 & 8,55 & & \\
\hline & \multirow[t]{2}{*}{ Communication } & ASF & 31 & 15,40 & 5,62 & \multirow{2}{*}{$-0,499$} & \multirow{2}{*}{0,618} \\
\hline & & IA & 30 & 16,18 & 6,89 & & \\
\hline & \multirow[t]{2}{*}{ Alienation } & ASF & 31 & 18,50 & 5,14 & \multirow{2}{*}{$-1,367$} & \multirow{2}{*}{0,172} \\
\hline & & IA & 30 & 16,00 & 6,90 & & \\
\hline & \multirow[t]{2}{*}{ Attachment } & ASF & 31 & 54,66 & 14,87 & \multirow{2}{*}{$-0,208$} & \multirow{2}{*}{0,835} \\
\hline & & IA & 30 & 52,36 & 19,38 & & \\
\hline
\end{tabular}

Table 3: IPPA- short form

\begin{tabular}{|c|c|c|c|c|c|c|c|c|c|c|c|c|c|c|}
\hline & & & \multicolumn{12}{|c|}{ FATHER } \\
\hline & & & \multicolumn{5}{|c|}{ Control } & \multicolumn{3}{|c|}{ Experimental } & \multicolumn{4}{|c|}{ Total } \\
\hline & & & $\stackrel{\vec{s}}{\overrightarrow{3}}$ & 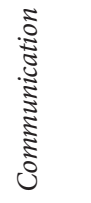 & 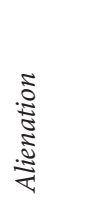 & 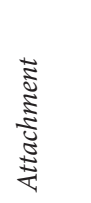 & $\stackrel{\vec{s}}{\vec{s}}$ & 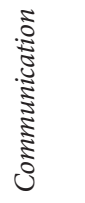 & 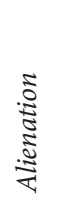 & 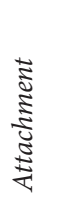 & $\stackrel{\overrightarrow{3}}{\overrightarrow{3}}$ & 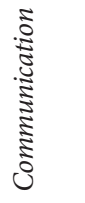 & 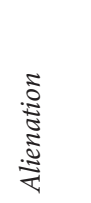 & 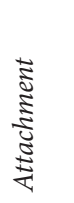 \\
\hline \multirow{8}{*}{ 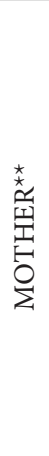 } & \multirow[b]{2}{*}{ Trust } & $\mathrm{r}$ & , 165 & 093 & , 185 & 244 &,- 142 &,- 017 &, 178 & 260 &,- 026 & ,003 &, 221 &, $305^{\star}$ \\
\hline & & $\mathrm{p}$ & ,385 & ,627 & ,328 &, 194 & ,470 & ,932 & ,355 &, 174 & ,846 & 981 & ,092 & 019 \\
\hline & \multirow{2}{*}{ Communication } & $\mathrm{r}$ &, $434^{*}$ &, $545^{\star}$ &, 351 &, $409^{\star}$ & ,098 & ,226 &, 252 & ,303 & 240 &, $341^{\star}$ &, $319^{*}$ &, $379^{*}$ \\
\hline & & $\mathrm{p}$ &, 016 &, 002 &, 057 & ,025 &, 621 & 248 &, 187 &, 110 &, 069 & ,009 &, 014 &, 003 \\
\hline & \multirow{2}{*}{ Alienation } & $\mathrm{r}$ &, $503^{\star}$ &, $454^{*}$ &, $437^{\star}$ &, $497^{\star}$ & ,058 &, 243 &, 111 &, 169 &, 213 &, $311^{*}$ & ,237 &, $297^{*}$ \\
\hline & & $\mathrm{p}$ & ,005 & ,012 & ,016 & ,005 &, 770 & 213 &, 568 & ,381 & , 109 & 017 &, 071 &, 022 \\
\hline & \multirow{2}{*}{ Attachment } & $\mathrm{r}$ &, $425^{*}$ &, $449^{*}$ &, $386^{*}$ &, $476^{*}$ &,- 054 &, 132 &, 213 & ,091 & ,138 & 238 &, $308^{*}$ & ,255 \\
\hline & & $\mathrm{p}$ & ,022 &, 014 & ,039 &, 010 & 800 &, 538 &, 318 & 679 & ,325 & ,086 &, 025 &, 071 \\
\hline
\end{tabular}

\footnotetext{
*: Statistically significant. ${ }^{* *}$ : Measured separately for each group.
} 
A negative correlation has been identified between participants' education level and their attachment to mother scores in experimental group $(\mathrm{r}=-0,50 ; \mathrm{p}=0,012)$. A low, negative correlation was also found demonstrating the association between the age of placement in institutions and delay of gratification scores of RLRS $(\mathrm{r}=0,37 ; \mathrm{p}=0,04)$, as these points increased in line with the age of individuals in experimental group. A moderate negative correlation was found between the education level of individuals in experimental group and management of impulses and implementation of planned behavior scores of RLRS $(r=-0,41 ; p=0,024)$. Accordingly, as the level of education subsides, an increase in scores of 'management of impulses and implementation of planned behavior' can be seen. A statistically significant negative correlation was identified between the number of staff available to take care of IA and 'seeking help' in RLRS ( $r=0,38 ; \mathrm{p}=0,048)$. This finding shows an increase in scores of seeking help that rises in line with a fall in the number of supportive staff.

According to Table 7, around a quarter of those in institutions $(13,3 \%)$ seek help from principal in times of stress, with only 2 respondents (6,7\%) seeking help from principal and on-hand psychologists, five individuals $(16,7 \%)$ seek help from only social workers and only one individual (3,3\%) seeks help from both social workers and psychologists. 16 individuals from experimental group $(53,3 \%)$ reported that they seek help from psychologists in times of stress.

According to the data presented on Table 8, those most sought for help among IA included social workers and psychologists. In line with this finding, it pays to investigate the attachment styles of these youths in terms of AAS and their

Table 4: Psychometric Properties of AAS

\begin{tabular}{|c|c|c|c|}
\hline Attachment Type & Control & Experimental & Total \\
\hline $\begin{array}{l}\text { I am somewhat uncomfortable being close to others; I find it difficult to trust } \\
\text { them completely, difficult to allow myself to depend on them. I am nervous when } \\
\text { anyone gets too close, and often, love partners want me to be more intimate than } \\
\text { I feel comfortable being (Avoidant) }\end{array}$ & $4(\% 14,3)$ & $18(\% 62,1)$ & $22(\% 38,6)$ \\
\hline $\begin{array}{l}\text { I find that others are reluctant to get as close as I would like. I often worry that } \\
\text { my partner doesn't really love me or won't want to stay with me. I want to merge } \\
\text { completely with another person, and this desire sometimes scares people away } \\
\text { (Anxious/Ambivalent) }\end{array}$ & $6(\% 21,4)$ & $1(\% 3,4)$ & $7(\% 12,3)$ \\
\hline $\begin{array}{l}\text { I find it relatively easy to get close to others and am comfortable depending on } \\
\text { them and having them depend on me. I don't often worry about being abandoned } \\
\text { or about someone getting too close to me (Secure) }\end{array}$ & $18(\% 64,3)$ & $10(\% 34,5)$ & $\% 49,1)$ \\
\hline
\end{tabular}

Table 5: AAS and IPPA-short form

\begin{tabular}{|c|c|c|c|c|}
\hline \multirow[b]{2}{*}{ IPPA sub-dimensions } & & \multicolumn{3}{|c|}{ Adult Attachment Scale - AAS } \\
\hline & & Control & Experimental & Total \\
\hline \multirow[t]{2}{*}{ Mother Trust } & $\mathrm{R}$ & ,355 &, 291 &, $332^{*}$ \\
\hline & $\mathrm{P}$ &, 064 & ,126 &, 012 \\
\hline \multirow[t]{2}{*}{ Mother Communication } & $\mathrm{R}$ &, $548^{\star}$ & 132 &, $318^{*}$ \\
\hline & $\mathrm{P}$ & ,003 & ,494 &, 016 \\
\hline \multirow[t]{2}{*}{ Mother Alienation } & $\mathrm{R}$ &, 126 &,- 075 &, 076 \\
\hline & $\mathrm{P}$ &, 524 & ,698 &, 576 \\
\hline \multirow[t]{2}{*}{ Mother Attachment } & $\mathrm{R}$ &, $462^{\star}$ & 081 &, $332^{*}$ \\
\hline & $\mathrm{P}$ & 015 & ,682 & 017 \\
\hline \multirow[t]{2}{*}{ Father Trust } & $\mathrm{R}$ &,- 033 &,- 208 &,- 085 \\
\hline & $\mathrm{P}$ &, 867 & ,298 &, 538 \\
\hline \multirow[t]{2}{*}{ Father Communication } & $\mathrm{R}$ & ,152 &,$- 386^{*}$ &,- 192 \\
\hline & $\mathrm{P}$ & ,439 & 046 &, 159 \\
\hline \multirow[t]{2}{*}{ Father Alienation } & $\mathrm{R}$ &,- 110 &,- 187 &,- 044 \\
\hline & $\mathrm{P}$ &, 578 & ,342 & ,749 \\
\hline \multirow[t]{2}{*}{ Father Attachment } & $\mathrm{R}$ & ,169 &,- 193 &,- 082 \\
\hline & $\mathrm{P}$ & ,431 & ,366 & ,565 \\
\hline
\end{tabular}


links to seeking help from psychologists and social workers. As seen on Table 8, any significant positive correlation cannot be derived from the data about the relationship between seeking help from both social worker/psychologist and attachment security among IA ( $>$.05).

\section{Discussion}

When we take into consideration overall results, it is hard to draw a general conclusion stating that attachment insecurity of IA is higher than ASF with a significantly low level of LR. Thus, all specific correlations and causalities gathered from the data should to be analyzed and discussed in a detailed way depending on sub-dimensions of scales used in the study.

When we start with the results of IPPA-short form demonstrated no significant difference between attachment patterns of experimental group $(\mathrm{M}=54,66 \pm 14,87)$ and control group ( $M=52,36 \pm 19,38)$, which could be caused by their ability to feel connected to their institution and staff. Another reason for this may be the quality of close peer relationships in institutions. Although those findings seem very positive and motivating at first glance, this may lead them to suffer from a second trauma when the time for separation from institution is up. Surprisingly, variation between the control and experimental groups found to be statistically significant. More specifically, IA is found to be more avoidant than ASF. Those results seem quite similar with the findings of recent research carried out by Yildiz and Bilge (2020), demonstrating a significant difference between IA and ASF in terms of avoidant/dismissive attachment type, social phobia and somatic symptom disorder. Differences were identified between IA and ASF in terms of attachment styles and averages of psychopathologies and researchers attributed these results to psychologically informed improvements of institutions.

Upon analyzing the mother and father sections of the IPPA-short from, a significant relation can be spotted between the total attachment scores of the former and the latter. This indicates the parallel nature of the proximity of the link between the adolescent and their father or mother. Such findings demonstrate similarities with those conducted in previous studies using a number of variables in relation to

Table 6: Psychometric Properties of RLRS

\begin{tabular}{|c|c|c|c|c|c|c|}
\hline RLRS Sub-dimensions & & $N$ & & Ss & $Z$ & $P$ \\
\hline \multirow{2}{*}{ Implementation of Planned Behavior } & Control & 31 & 11,81 & 3,52 & \multirow{2}{*}{$-2,347$} & \multirow{2}{*}{$0,019^{*}$} \\
\hline & Experiment & 30 & 14,03 & 3,87 & & \\
\hline \multirow{2}{*}{ Delay of Gratification } & Control & 31 & 11,90 & 2,55 & \multirow{2}{*}{$-2,130$} & \multirow{2}{*}{$0,033^{*}$} \\
\hline & Experiment & 30 & 13,90 & 3,69 & & \\
\hline \multirow{2}{*}{ Mood-management } & Control & 31 & 13,00 & 3,11 & \multirow{2}{*}{$-1,841$} & \multirow{2}{*}{0,066} \\
\hline & Experiment & 30 & 11,13 & 4,03 & & \\
\hline \multirow{2}{*}{ Management of unwanted thoughts } & Control & 31 & 6,17 & 1,23 & \multirow{2}{*}{$-0,237$} & \multirow{2}{*}{0,813} \\
\hline & Experiment & 30 & 6,07 & 1,74 & & \\
\hline \multirow{2}{*}{ Management of impulses and Implementation of Planned Behavior } & Control & 31 & 13,06 & 2,38 & \multirow{2}{*}{$-1,078$} & \multirow{2}{*}{0,281} \\
\hline & Experiment & 30 & 13,87 & 2,52 & & \\
\hline \multirow{2}{*}{ Self-sufficiency and self-support } & Control & 31 & 14,00 & 2,91 & \multirow{2}{*}{$-0,517$} & \multirow{2}{*}{0,605} \\
\hline & Experiment & 30 & 14,37 & 3,09 & & \\
\hline \multirow{2}{*}{ Pain management } & Control & 31 & 5,94 & 1,88 & \multirow{2}{*}{$-0,687$} & \multirow{2}{*}{0,492} \\
\hline & Experiment & 30 & 6,37 & 2,43 & & \\
\hline \multirow{2}{*}{ Seeking help } & Control & 31 & 10,00 & 2,11 & \multirow{2}{*}{$-1,646$} & \multirow{2}{*}{0,100} \\
\hline & Experiment & 30 & 10,87 & 2,89 & & \\
\hline \multirow{2}{*}{ Favorable interpretation of events } & Control & 31 & 9,97 & 2,24 & \multirow{2}{*}{$-2,574$} & \multirow{2}{*}{$0,010^{\star}$} \\
\hline & Experiment & 30 & 8,37 & 2,30 & & \\
\hline \multirow{2}{*}{ Careful supervising) } & Control & 31 & 9,55 & 2,14 & \multirow{2}{*}{$-0,995$} & \multirow{2}{*}{0,320} \\
\hline & Experiment & 30 & 10,00 & 3,01 & & \\
\hline \multirow{2}{*}{ Flexible planning } & Control & 31 & 6,17 & 1,23 & \multirow{2}{*}{$-0,237$} & \multirow{2}{*}{0,813} \\
\hline & Experiment & 30 & 6,07 & 1,74 & & \\
\hline & Control & 31 & 13,06 & 2,38 & & \\
\hline seeking supervisor & Experiment & 30 & 13,87 & 2,52 & $-1,0 / 0$ & 0,201 \\
\hline
\end{tabular}


Table 7: IPPA and RLRS Relationship of Institutionalized Adolescents

\begin{tabular}{|c|c|c|c|c|c|}
\hline & & Education & Age of placement & Duration & Staff \\
\hline \multirow{2}{*}{ AAS } & $\mathrm{R}$ &,- 144 & $-0,319$ & $-0,195$ & $-0,203$ \\
\hline & $\mathrm{P}$ & ,455 & 0,092 & 0,319 & 0,320 \\
\hline \multirow{2}{*}{ Mother Trust } & $\mathrm{R}$ &,- 271 &,- 093 &, 031 &,- 175 \\
\hline & $\mathrm{P}$ &, 147 &, 627 & ,873 & ,382 \\
\hline \multirow{2}{*}{ Mother Communication } & $\mathrm{R}$ &,- 332 &,- 255 & 042 &, 052 \\
\hline & $\mathrm{P}$ & ,073 &, 174 & ,831 & ,797 \\
\hline \multirow{2}{*}{ Mother Alienation } & $\mathrm{R}$ &,- 313 &,- 136 & ,206 &, 007 \\
\hline & $\mathrm{P}$ & ,092 & ,472 & ,285 & ,972 \\
\hline \multirow{2}{*}{ Mother Attachment } & $\mathrm{R}$ &,$- 494^{*}$ &,- 274 &, 254 &,- 062 \\
\hline & $\mathrm{P}$ & ,012 &, 185 &, 231 & ,777 \\
\hline \multirow{2}{*}{ Father Trust } & $\mathrm{R}$ & ,046 &, 011 & ,001 &, 220 \\
\hline & $\mathrm{P}$ & ,817 & ,958 & 998 & 281 \\
\hline \multirow{2}{*}{ Father Communication } & $\mathrm{R}$ &, 139 & 084 & 088 &,- 073 \\
\hline & $\mathrm{P}$ & 481 & 670 & ,662 & ,722 \\
\hline \multirow{2}{*}{ Father Alienation } & $\mathrm{R}$ &,- 124 &,- 213 & 186 & 235 \\
\hline & $\mathrm{P}$ &, 522 &, 267 & ,343 & 248 \\
\hline \multirow{2}{*}{ Father Attachment } & $\mathrm{R}$ &,- 167 &,- 015 & ,290 &, 001 \\
\hline & $\mathrm{P}$ & ,426 & ,942 &, 168 & ,997 \\
\hline \multirow{2}{*}{ Implementation of Planned Behavior } & $\mathrm{R}$ &,- 271 & 227 &,- 279 &,- 286 \\
\hline & $\mathrm{P}$ &, 148 & 227 & 143 & ,148 \\
\hline \multirow{2}{*}{ Delay of Gratification } & $\mathrm{R}$ &,- 263 &,$- 371^{*}$ &,- 103 &,- 267 \\
\hline & $\mathrm{P}$ &, 160 & ,043 &, 596 &, 177 \\
\hline \multirow{2}{*}{ Mood Management } & $\mathrm{R}$ & ,087 &, 220 &,- 214 &, 110 \\
\hline & $\mathrm{P}$ & 649 & 243 & ,265 &, 585 \\
\hline \multirow{2}{*}{ Management of Unwanted Thoughts } & $\mathrm{R}$ &,- 051 &,- 249 &,- 042 &,- 186 \\
\hline & $\mathrm{P}$ & ,789 &, 184 & ,828 & ,352 \\
\hline \multirow{2}{*}{$\begin{array}{l}\text { Management of Impulses and Implementation of Planned } \\
\text { Behavior }\end{array}$} & $\mathrm{R}$ &,$- 411^{*}$ &,- 177 &, 113 &,- 159 \\
\hline & $\mathrm{P}$ & 024 & ,349 &, 561 & ,429 \\
\hline \multirow{2}{*}{ Self-sufficiency and Self-support } & $\mathrm{R}$ &,- 305 & ,009 &, 122 & 083 \\
\hline & $\mathrm{P}$ &, 101 & ,962 &, 529 & 680 \\
\hline \multirow{2}{*}{ Pain Management } & $\mathrm{R}$ &,- 120 & ,218 & ,195 & ,033 \\
\hline & $\mathrm{P}$ &, 527 &, 246 &, 311 &, 868 \\
\hline \multirow{2}{*}{ Seeking Help } & $\mathrm{R}$ & 158 &, 323 &,- 015 &,$- 383^{\star}$ \\
\hline & $\mathrm{P}$ & ,403 & 082 & 940 & ,048 \\
\hline
\end{tabular}

the IPPA form (Laible, Carlo \& Roesch, 2004; Liable, 2006). In this study, the IPPA-short form and AAS data diverged, with the former showing secure attachment and the latter showing insecure attachment.

According to the findings attained over the course of the study, as the age of the experiment group increased a similar increase in scores can be seen for each of the sub dimensions of the RLRS. Upon reviewing the current literature for learned resourcefulness, it appears that the phenomenon is a cognitive skill that begins to develop at an early age and matures with time - and this finding seems parallel with the previous findings in the literature (Coskun, 2009; Akca, 2011). Any significant relationship found between age and attachment styles could be explained by the fact almost all respondents were still in the similar developmental phase.

According to the data gathered from the IPPA-short forms, a significant reverse correlation could be found between father's education level and secure attachment to mother, with a lower attachment in terms of the latter decreasing in line with an increase in the former. Additionally, a significant 
Table 8: Association Between AAS and 'Seeking Help' as a sub-dimension of RLRS

\begin{tabular}{llllll}
\hline & & Avoidant & Anxious & Secure & \\
\hline Psychologist & Not consulted & 7 & 1 & 1 & $\mathrm{r}=0,28$ \\
& Consulted & 11 & 0 & 9 & $\mathrm{p}=0,14$ \\
Social Worker & Not consulted & 13 & 1 & 9 & $\mathrm{r}=-0,21$ \\
& Consulted & 5 & 0 & 1 & $\mathrm{p}=0,27$ \\
\hline
\end{tabular}

association between the 'seeking help' sub-dimension of RLRS and education level of mothers. Upon an analysis of the literature, there is a close link between the level of education of mothers and their neglectful and abusive behaviors toward their children, with a higher chance of the latter among those whose mothers have a low level of education (Guler et al., 2002; Dallar Bilge et al., 2013). It is thus not unforeseen that children who have been neglected or abused by parents are limited in terms of 'seeking help' from them. According to a study from Turkel and Tezel (2008), children who perceive their parents as neglectful and authoritarian are more likely to exhibit low levels of learned resourcefulness. Increased level education of mothers predicts lower chances of neglect or abuse to their own offspring, which in turn may affect participants' learned resourcefulness.

According to the results of the Turkish Adolescent Profile Study conducted by Ministry of Family and Social Policy of the Republic of Turkey (2008), 89.5\% of the mothers of adolescents were housewives and $25.3 \%$ of fathers of them were unqualified workers due to their education level. In times of stressful life conditions youths who have experienced violence from family members found to be ignore dealing with them or totally become desensitized. These findings are in line with the previous studies as a sign of low LR.

Upon analyzing the findings regarding the age of placement among the experimental group, in contrast to expectations there was not found a positive correlation between age of placement and attachment insecurity. In other words, a positive correlation was found in terms of secure attachment pattern, which increased according to how early the respondents were placed into institutions. Previous studies in the literature also bear out this link (Stovall-McClough \& Dozier, 2004; Van Ijzendoorn \& Juffer, 2006; van den Dries et al., 2009). As the result of a study by Hortacsu, Cesur and Oral (1993) in Turkey, a clear relationship was established between youths who are split from their parents at a younger age and secure attachment. There are a number of reasons that could account for this regressive result: Firstly, the duration of residing in institutional care varied from less than one month to a maximum of seven years, but when the precise figures are calculated, they come to an average period of 22 months. The 'feeling of security' thus could come as a result that the adolescents at these institutions, who have grown up with rather chaotic experiences, find themselves in a place that can at least provide them 'felt security' (Sroufe \& Waters, 1977, s. 1186).

A negative correlation was proven when compared to the 'delay of gratification' sub-dimension of the RLRS and age of placement in institutional care $(\mathrm{p}<.05)$. It appears that points for the latter, as a sign of high level of LR, as well as an active coping mechanism, increase in line with how young an adolescent was sent into care. Attachment security might play a mediatory role in this relationship as there was a positive correlation found between early placement and attachment security according to our findings. Delay of gratification simply refer to the ability to exert self-regulation despite temptations which is mostly related with attachment security. Individuals with attachment security are found to be able exhibit more self-control (Fonagy et al., 2008). Children with higher attachment security were found to be more capable to wait the longest period (Jacobsen et al., 1997; Mittal et al., 2013). In a meta-analysis including 101 studies participants whose ages up to 18 years of age has revealed a positive relation between quality of attachment and self-regulation (Pallini et al., 2018). Due to their trusting view of the outside world, securely attached individuals face stressful situations by emotionally or purposefully asking for help without issue and aim to actively face their problems head on (Mikulincer, Florian \& Weller, 1993, Mikulincer \& Florian, 1997, Schottenbauer, 2006).

An important finding emerged in that social care specialists and psychologists ranked top along the hierarchy of those working at institutions who the participants of experimental group would go to in times of need and stress. The findings are key to confirming that the adolescents felt as though by expressing their problems to experts in mental health that they were in a position to help. While this finding seems to contradict the results of Davulcu's (2018) study revealing that Turkish institutionalized children prefer to get support mostly from the principals of the institutions, it seems to support the monotropy rule of Bowlby's (1969/1982) attachment theory in that the interactivity of institutionalized children afforded by a certain number of care worker leads to each child seeking a certain member of staff when in times of need or stress. This is because at the top of the hierarchy of care workers sits whoever among them is most engaged with the child during difficult times (Berlin, Cassidy \& Aplleyard, 2008). Furthermore, a moderate, negative relationship has been found between the number of those on hand for those living in institutional care and the number of points on the 'seeking help' subdivision of the RLRS ( $\mathrm{r}=-0,38 ; \mathrm{p}=0,048)$.

In this regard, the results of the RLRS are of great importance, institutions are known as being able to provide youth with care and protection in the physical sense, they remain inadequate in terms of compensating and reforming their attachment relations, which is an essential component of 
rehabilitation (Yolcuoglu, 2009; Bayoglu \& Purutcuoglu, 2011). The absence of a single individual offering personal care and for each child renders it impossible for the child to develop patterns of attachment or compensate for the deprivation they experienced in the past. Thus, a social worker who is specifically responsible from sensitive care can give attention to each child is extremely importance. Although the results of the study did not suggest a significant direct link between secure attachment and a lower number of staff at institutions, the findings of the RLRS certainly supported such a direct link.

In terms of the link between the AAS and RLRS, attachment security significantly predicted the 'planned behavior' sub-dimension of RLRS for the control group. Another significant prediction was identified between 'self-sufficiency and self-support' sub-dimension of RLRS attachment security. Findings demonstrate that those with secure attachment styles are more prone to self-soothing and coper better by a healthy emotion and self-regulation strategies. In other words, they more secure individuals have more success in retaining self-control in times of stress. Thus, the findings of this study support are consistent with previous research in the current literature (Weinfield et al., 2008; Vaughn, Bost and Van Ijzendoorn, 2008; Masterson, 2008; Pallini et al., 2018; Heylen et al., 2019). Furthermore, it can be shown that the prone an adolescent living with their family is to secure attachments, the higher the level of their mechanisms for self-control, exhibiting higher levels of 'self-sufficiency and self-support' as a sign of greater learned resourcefulness. These findings fall in line with that of the study by Dilmac, Hamarta and Arslan (2009), in which a positive correlation was confirmed between secure attachments and internal locus of control as a self-control strategy. A significant difference was identified between experimental and control group in terms of 'Favorable interpretation' sub-dimension of RLRS as a kind of cognitive flexibility. This finding is in line with the data in the literature (Doron et al., 2009; Fathi-Ashtiani \& Sheiholeslami, 2019; Aghai \& Mousavi, 2020; Baradaran \& Noushari, 2021). For example, a very significant evidence found for a mediational model on Australian population including 467 student participants ( $\mathrm{M}$ age $=21,3$ yrs; $81 \%$ female) where attachment orientations contributed to dysfunctional cognitive beliefs linked with OCD and obsessive compulsive symptoms (Doron et al., 2009). The results of another research done by Fathi-Ashtiani and Sheiholeslami (2019) on 272 adult participants revealed that adult attachment style had predicted the cognitive flexibility of individuals. Furthermore, a strong negative correlation found between attachment security and cognitive flexibility of 300 individuals $(\mathrm{p}<0.01)$ (Aghai and Mousavi, 2020). According to the results of a another study, while there is a negative correlation between cognitive flexibility and preoccupied/anxious attachments, there is a due positive correlation with secure attachments in line with previous studies. These findings back up the idea that this concept has consequences for one's problem-solving and coping strategies. A positive correlation also appears between coping and low levels of anxious/insecure attachment (Galatzer-Levy \& Bonanno, 2013). This finding also reflects the observation that the lower the anxiety level, the higher the ability to cope. Along with cognitive flexibility, the ability to control one's levels of anxiety is also important. Thus, it can be argued that cognitive flexibility is a skill that is shaped by social interactions from cradle to grave. Thus, those with sufficient level of cognitive flexibility can form alternative ideas (favorable interpretation) in the face of situations that appear to be negative (Gunduz, 2013).

\section{Strengths and Limitations}

As noted previously, to our knowledge this is the first study to examine the institutionalized adolescents' attachment relationships and LR in comparison with normal population. First, much more research must be done to explore the association between attachment and LR of institutionalized youth in comparison with normal population. Second, our method was retrospective in nature and only able to determine their existent state of mind regarding their attachment and LR. Third, this study has limitations of being cross-sectional. Fourth, it was assumed that all scales are completed properly although half of the participants consist of institutionalized adolescents who may have serious cognitive problems and psychopathologies which my hinder their duration of concentration and attention skills. Finally, in spite of achieving its goals it is possible that some theoretically interesting findings might have been missed.

\section{References}

Aghai, A. \& Mousavi, M. S. (2020). The relationship between attachment styles with self-differentiation, cognitive flexibility and marital intimacy in students. Rooyesh-e-Ravanshenasi, 9(2). 109-116.

Ainsworth, M. D. S., Blehar, M. C., Waters, E., \& Wall, S. (1978). Patterns of attachment: A psychological study of the strange situation. Erlbaum.

Akca, F. (2011). The relationship between test anxiety and learned helplessness. Social Behavior and Personality, 39(1): 101-112.

Arslan, C., Dilmac, B. \& Hamarta, E. (2009). Coping with stress and trait anxiety in terms of locus of control. Social Behavior and Personality, 37(6), 791-800.,

Ashtiani-Fathi, M. \& Sheikholeslami, R. (2019). Relationship between attachment style and psychological well-being: the mediating role of cognitive flexibility. Journal of Psychology, 23, 134-147.

Baradaran, M. \& Noushari, F. R. (2021). The role of cognitive flexibility and attachment style as predictors of student social cognition. Social Welfare Quarterly, 21(80).

Bartholomew, K. \& Horowitz, L. M. (1991). Attachment styles among young adults: a test of a four-category model. Journal of Personality and Social Psychology, 61(2), pp.226-144. 
Bayoglu, A. S. \& Purutcuoglu, E. (2011). Yetiştirme yurdunda kalan ergenlerin gelecek beklentileri ve sosyal destek algıları. Kriz Dergisi, 18(1), pp. 27-39.

Ben-Ari, R. \& Hirshberg, I. (2009). Attachment Styles, Conflict Perception, and Adolescents' Strategies of Coping with Interpersonal Conflict. Negotiation Journal, 25(1), 59-82.

Berlin, L. J., Cassidy, J., \& K. (2008). The Influence of Early Attachments on Other Relationships. In J. Cassidy and P. R. Shaver (Eds). Handbook of Attachment: Theory, Research, and Clinical Applications. The Guildford Press.

Bowlby, J. (1969/1982). Attachment and loss: Vol. 1. Attachment. Basic Books.

Bowlby, J. (1973). Attachment and loss: Vol. 2. Separation: Anxiety and Anger. Basic Books.

Bowlby, J. (1979). The making and breaking of affectional bonds. Tavistock.

Bowlby, J. (1980). Attachment and loss: Vol. 3. Loss: Sadness and Depression. Basic Books.

Bowlby, J. (1988). A secure base: Clinical application of attachment theory. Basic Books.

Boyraz, G. \& Aydin, G. (2003). Yetiştirme yurdu ve anne-baba yanında kalan ergenlerde öğrenilmiş güçlülük. Turkish Psychological Counseling and Guidance Journal, 2(20), 59-64.

Breidenstine, A. S., Bailey, L. O, Zeanah, C. H., \& Larrieu, J. A (2011). Attachment and trauma in early childhood: A review. Journal of Child \& Adolescent Trauma, 4, pp. 274-290.

Cassidy, J. (1994). Emotion regulation: Influences of attachment relationships. Monographs of the Society for Research in Child Development, 59(2-3), 228-283.

Ceyhan, A. A. (2006). The Prediction of learned resourcefulness, anxiety, and psychological symptoms from early separation anxiety. Educational Sciences: Theory \& Practice, 6(1), pp. 72-79.

Cifci, E. G. A., Kardes, T., Yanardag, M. Z. \& Akgun, R. (2016). Türkiye' de kurum bakımı deneyimi olan bireylerin iş ve yaşam doyumlarının incelenmesi üzerine bir araştırma: Ankara İli örneği. Sosyal Politikalar Çalışmaları Dergisi, 37, 9-31.

Coskun, Y. (2009). Ortaöğretim öğrencilerinin öğrenilmiş güçlülük düzeyleri ve aile içi ilişkileri. Sosyal Bilimler Enstitürü Dergisi, 18(2), 104-118.

Cutrona, C. E. (1990). Stress and Social Support: In Search of Optimal Matching. Journal of Social and Clinical Psychology, 9, 3-14.

Dag, I. (1991). Rosenbaum'un öğrenilmiş güçlülük ölçeği'nin üniversite öğrencileri için güvenilirliği ve geçerliliği. Türk Psikiyatri Dergisi, 2(4), 269- 274.

Dallar Bilge, Y., Tasar, M. A., Klilincoglu, B., Ozmen, S and Tiras, U. (2013). Alt sosyoekonomik düzeye sahip anne-babaların çocuk istismarı ve inmali hakkındaki bilgi düzeyleri, deneyimleri ve kullandıkları disiplin yöntemleri. Türk Psikiyatri Dergisi, 14, 27-35.

Davulcu, U. S. (2018). Çocuk evleri sitesinde kalan çocukların algıladıkları sosyal destek ve beklentileri. Kocaeli University, Institute of Medical Science, Master Thesis, Kocaeli.

Dilmac, B., Hamarta, E. \& Arslan, C. (2009). Üniversite öğrencilerinin sürekli kaygı ve denetim odaklarının bağlanma stilleri açısından incelenmesi. Kuram ve Uygulama Eğitim Bilimleri, 9(1), pp. 127-159.

Doron, G., Moulding, R., Kyrios, M., Nedeljkovic, M., \& Mikulincer, M. (2009). adult attachment insecurities are related to obsessive compulsive phenomena. Journal of Social and Clinical Psychology, 28(8), 1022-1049.
Dozier, M. \& Rutter, M. (2008). Challenges to the development of attachment relationships faced by young children in foster and adoptive care. J. Cassidy \& P. R. Shaver (Eds). Handbook of Attachment: Theory, Research, and Clinical Applications (pp. 698-744). The Guildford Press.

Dozier, M., Stovall, C., Albus, K., \& Bates, B. (2001). Attachment for infants in foster care: The role of caregiver state of mind. Child Development, 72, pp. 1467-1477.

Eroglu, Y., Akbaba, S., Adiguzel, O. \& Peker, A. (2014). Learned resourcefulness and coping with stress in mothers of children with disabilities. Eurasian Journal of Educational Research, 55, pp. 243-262.

Fathi-Ashtiani, M. \& Sheikholeslami, R. (2019). Relationship between attachment style and psychological well-being: The mediating role of cognitive flexibility. Journal of Psychology, 23, 134-147.

Fonagy, P., Gergely, G., \& Target, M. (2008). Psychoanalytic constructs and attachment theory and research. In Handbook of Attachment: Theory, Research, and Clinical Applications (pp. 783- 810). The Guildford Press.

Fraley, R. C., \& Waller, N. G. (1998). Adult attachment patterns: A test of the typological model. In J. A. Simpson \& W. S. Rholes (Eds.), Attachment theory and close relationships (pp. 77-114). The Guilford Press.

Galatzer-Levy, I. R. \& Bonanno, G. A. (2013). Heterogeneous patterns of stress over the four years of college: associations with anxious attachment and ego-resiliency. Journal of Personality, 81(5): 476-486.

Gintner, G. G., West, J. D., \& Zarski, J. J. (2001). Learned resourcefulness and situation- specific coping with stress. The Journal of Psychology, 123(3), pp. 295-304.

Guler, N., Uzun, S., Boztas, Z. \& Aydogan, S. (2002). Anneleri tarafindan çocuklara uygulana duygusal ve fiziksel istismar/ ihmal davranışı ve bunu etkileyen faktörler. Cumhuriyet Üniversitesi Tıp Fakültesi Dergisi, 24(3):128-134.

Gunaydin, G., Selcuk, E., Sumer, N., \& Uysal, A. (2005). Yetişkin bağlanma boyutlan için yeni bir ölçüm: Yakın ilişkilerde yaşantılar envanteri-II'nin Türk örnekleminde psikometrik açidan değerlendirilmesi [A New Scale Developed to Measure Adult Attachment Dimensions: Experiences in Close Relationships-Revised (ECR-R) - Psychometric Evaluation in a Turkish Sample]. Türk Psikoloji Yazıları, 8(16), 1-11.

Gunduz, B. (2013). Bağlanma Stilleri, Akılcı Olmayan İnançlar ve Psikolojik Belirtilerin Bilişsel Esnekliği Yordamadaki Katkıları. Kuram ve Uygulamada Eğitim Bilimleri, 13(4), 2071-2085.

Hazan, C. \& Shaver, P. (1987). Love Conceptualized as an Attachment Process. Journal of Personality and Social Psychology, 52(3), pp. 511-524.

Hesse, E., \& Main, M. (2000). Disorganized infant, child, and adult attachment: Collapse in behavioral and attentional strategies. Journal of the American Psychoanalytic Association, 48(4), 1097-1127.

Heylen, J., De Raedt, R. Verbruggen, F. \& Bosmans, G. (2019). Attachment and self-regulation performance in preadolescence. Journal of Social and Personal Relationships, 36(2), 706-716.

HortaCsu, N., Cesur, S. \& Orak, A. (!993). Relationships between depression and attachment styles in parent-and institutionreared Turkish children. The Journal of Genetic Psychology, 154(3), 329-337., 
Huang, C., Sousa, V. D., Tu, S. \& Hwang, M. (2005). Depressive Symptoms and Learned Resourcefulness Among Taiwanese Female Adolescents. Archives of Psychiatric Nursing, 19(3), 133-140.

Jacobsen, T., Huss, M., Fendrich, M., Kruesi, M. J. P. \& Ziegenhain (1997). Children's Ability to Delay of Gratification: Longitudinal Relations to Mother-Child Attachment. The Journal of Genetic Psychology, 158(4), 411-426.

Levy, T. M. ve Orlans, M. (2000). Attachment Disorders as and Antecedent to Violence and Antisocial Patterns in Children. In Terry M. Levy (Ed.), Handbook of Attachment Interventions (p. 1-26). California: Academic Press.

Liable, D. (2006). Maternal emotional expressiveness and attachment security: links to representations of relationships and social behavior. Merrill-Palmer Quarterly, 42(4); 645-670.

Liable, D., Carlo, G. \& Roesch, S. C. (2004). Pathways to self-esteem in late adolescence: The role of parent and peer attachment, empathy, and social behaviors. Journal of Adolescence, 27 (6), 703-716

Liang, B., Williams, L. M., \& Siegel, J. A. (2006). Relational outcomes of childhood sexual trauma in female survivors: A longitudinal study. Journal of Interpersonal Violence, 21(1):42-57.

Main, M., \& Solomon, J. (1990). Procedures for identifying infants as disorganized / disoriented during the Ainsworth strange situation. In M. T. Greenberg, D. Cicchetti, and E. M. Cummings (Eds.), Attachment in the Preschool Years (pp. 121-160). University of Chicago Press.

Masterson, J. F. (2008). Bağlanma kuramı ve nörobiyolojik kendilik gelişimi açısından kişilik bozuklukları. Litera Yayıncılık

Meichenbaum, D. (1977). Cognitive-behavior modification: An integrative approach. Plenum Press.

Mikulincer, M., Florian, V., \& Weller, A. (1993). Attachment Styles, coping strategies, and posttraumatic psychological distress: The impact of the Gulf War in Israel. Journal of Personality and Social Psychology, 64(5): 817-826.

Mikulincer, M., \& Florian, V. (1997). Are emotional and Instrumental supportive interactions beneficial in times of stress? The impact of attachment style. Anxiety, Stress and Coping, 10, 109-127.

Mittal, R. Russel, B. S., Britner, P. A. \& Peake, P. K. (2013). Delay of gratification in two- and three-year-old: Associations with attachment, personality and temperament. Journal of Child and Family Studies, 22, 479-489.

Ana Fraga; Ana Maria Serrano; Susana Caires. "Children of parents with mental health vulnerability: implications and familycentered support". Journal for Educators, Teachers and Trainers, 10, 2, 2019, -

Ognibene, T. C. \& Collins, N. L. (2010). Adult Attachment Styles, Perceived Social Support and Coping Strategies. Journal of Social and Personal Relationships, 15(3); 323-345.

Ozturk E. (2018). Çocuk evleri sitesinde çalışan bakım elemanlarının problem çözme becerileri, öğrenilmiş güçlülük ve çocuk sevme düzeyleri arasındaki ilişki (Ankara Ili Örneği). Ankara University, School of Health Sciences, Master Thesis.

Pallini, S., Chirumbolo, A., Morelli, M., Baiocco, R., Laghi, F., \& Eisenberg, N. (2018). The relation of attachment security status to effortful self-regulation: A meta-analysis. Psychological Bulletin, 144(5), 501-531.
Pasyar, S., Rezaei, S. \& Mousavi, S. V. (2018). Stress-coping Strategies, Attachment Styles and Resiliency of Working Children in Tehran, Iran. Child Indicators Research, 12, 1083-1105.

Raja, S. N., McGee, R. \& Stanton, W. R. (1992). Perceived Attachments to Parents and Peers and Psychological Well-Being in Adolescence. Journal of Youth and Adolescence, 21(4), pp. 471-85.

Ronen, T. \& Rosenbaum, M. (2010). Developing learned resourcefulness in adolescents to help them reduce their agressive behavior: preliminary findings. Research on Social Work Practice, 21(4), pp. 410-426.

Rosenbaum M. (1983) Learned resourcefulness as a behavioral repertoire for the self-regulation of internal events: Issues and speculation. In Rosenbaum, M., Franks, C.M. \& Jaffee, Y. (Eds.), Perspectives on Behavior Therapy in the Eighties (pp. 54-73). Springer.

Rosenbaum, M. (1980). A schedule for assessing self-control behaviors: Preliminiary findings. Behavior Therapy, 11, p. 109-121.

Rosenbaum, M. \& Ben-Ari, K. (1985). Learned helplessness and learnes resurcefulness: Effects of noncontingent success and failure on individuals differing in self-control skills. Journal of Personality and Social Psychology, 48 (1), 198-215.

Rosenbaum, M. \& Jaffe, Y. (1983). The Role of Individual Differences in Learned Resorucefulness. Biritish Journal of Social Psychology, 22, pp.215-225.

Saglam, E. (2014). Yetiştirme yurdunda büyüyen genç yetişkinlerin bazı psikolojik özelliklerinin ailesi yanında büyüyen bireylerle karşılaştrılması. Maltepe University, Master Thesis.

Schottenbauer, M. A., Klimes-Dougan, B., Rodriguez, B. F., Arnkoff, S. B., Glass, C. R., \& Lasalle, V. H. (2006). Attachment and affective resolution following a stressful event: General and religious coping as possible mediators. Mental Health, Religion \& Culture, 9(5), 448- 471.

Simpson, J. A., \& Belsky, J. (2008). Attachment theory within a modern evolutionary framework. In J. Cassidy \& P. R. Shaver (Eds.), Handbook of attachment: Theory, research, and clinical applications (pp. 131-157). The Guilford Press.

Sroufe, L. A. \& Waters, E. (1977). Attachment as an Organizational Construct. Child Development, 48, pp. 1184-1199.

Sroufe, L. A. (2005). Attachment and development: a prospective, longitudinal study from birth to adulthood. Attachment \& Human Development, 7(4), 349-367.

Sroufe, L. A., Coffino, B., \& Carlson, E. A. (2010). Conceptualizing the Role of Early Experience: Lessons from the Minnesota Longitudinal Study. Developmental Review, 30(1), 36-51. https://doi.org/10.1016/j.dr.2009.12.002

Stovall-McClough, K. C., \& Dozier, M. (2004). Forming Attachments in Foster Care: Infant Attachment Behaviors During the First 2 Months. Development and Psychopathology, 16, pp. 253-271.

Thompson, R. A. (2008). Early attachment and later development. In J. Cassidy and P. R. Shaver, (Eds). The Handbook of Attachment: Theory, Research, and Clinical Applications (pp. 348-365). The Guildford Press.

Thompson, R. A., \& Newton, E. K. (2010). Emotion in early conscience. In W. F. Arsenio \& E. A. Lemerise (Eds.), Emotions, aggression, and morality in children: Bridging development and psychopathology (pp. 13-31). American Psychological Association. https://doi.org/10.1037/12129-001 
Thompson, R. A. (2010). Feeling and understanding through the prism of relationships. In S. D. Calkins \& M. A. Bell (Eds.), Child development at the intersection of emotion and cognition (pp. 79-95). American Psychological Association. https://doi. org/10.1037/12059-005

Turgut, A. S. (2018). Investigating the resilience degrees of individuals who grew in institutional care in Turkey, Master Thesis.

Turgut, A. S. \& Ozkan, Y. (2019). Investigating the relationship between socio-demographic attributes and problems after institutional care of care leavers. Türkiye Sosyal Araştirmalar Dergisi, 24(3), 748-763.

Turkel, Y. D. \& Tezer, E. (2008). Parenting styles and learned resourcefulness of Turkish adolescents. Adolescence, 43(169), 143-152.

Turkish Adolescent Profile Study (2008). Ministry of Family and Social Policy of Republic of Turkey.

Uluc, S. (2012). Doğuştan Getirilen iliş̧kisellik Arayışııın Ana Babayla Kurulan Duygusal Bağ Aracılığıyla Biçimlenmesi. Melike Sayıl and Bile Yağmurlu (Eds), Ana Babalık: Kuram ve Araştırma, (pp. 191-214). Koç Üniversitesi Yayınları.

Van den Dries, L., Juffer, F., van ljzendoorn, M. H., \& BakermansKranenburg, M. J. (2009). Fostering Security? A Meta-Analysis of Attachment in Adopted Children. Children and Youth Services Review, 31, 41-421.
Van Ijzendoorn, M. H., \& Juffer, F. (2006). The Emanuel Miller Memorial Lecture 2006: Adoption as Intervention. MetaAnalytic evidence for massive catch-up and plasticity in physical, socio-emotional, and cognitive development. Journal of Child Psychology and Psychiatry, 47(12), 12281245.

Vaughn, B. E., Bost, K. K. \& Van ljzendoorn, M. H. (2008). Attachment and Temperament: additive and interactive influences on behavior, affect, and cognition during infancy and childhood. In J. Cassidy and P. R. Shaver, (2008). Handbook of Attachment: Theory, Research, and Clinical Applications (pp.192-216). Guildford Press.

Weinfield, N. S., Sroufe, L. A., Egeland, B. \& Carlson, E. (2008). Individual differences in infant-caregiver attachment. In Jude Cassidy and Philip R. Shaver (Eds.). Handbook of Attachment: Theory, Research, and Clinical Applications (pp. 78-101). Guildford Press.

Yildiz, A. \& Bilge, Y. (2020). Examination of male adolescents' psychological disorders living in the Children's Homes and with their families in terms of attachment styles, and emotion regulation. Toplum ve Sosyal Hizmet, 31(4), 1459-1485.

Yolcuoglu, I. G. (2009). Türkiye'de çocuk koruma sisteminin genel olarak değerlendirilmesi. Aile ve Toplum Dergisi, 5(18), pp. 1-20. 